\title{
Evaluasi Hasil dan Kandungan Pati Mutan Ubi Kayu Hasil Iradiasi Sinar Gamma Generasi $\mathbf{M}_{1} \mathbf{V}_{4}$
}

\author{
Yield and Starch Content Evaluation of Gamma Irradiated Cassava Mutants at $M_{1} V_{4}$ Generation
}

\author{
Isnani Subekti', Nurul Khumaida ${ }^{2 *}$, Sintho Wahyuning Ardie², dan Muhamad Syukur ${ }^{2}$ \\ ${ }^{1}$ Program Studi Pemuliaan dan Bioteknologi Tanaman, Sekolah Pascasarjana, Institut Pertanian Bogor \\ ${ }^{2}$ Departemen Agronomi dan Hortikultura, Fakultas Pertanian, Institut Pertanian Bogor \\ (Bogor Agricultural University), Jl. Meranti, Kampus IPB Darmaga, Bogor 16680, Indonesia
}

Diterima 19 September 2017/Disetujui 29 Desember 2017

\begin{abstract}
Cassava is one of the important starch producer crops. Although Indonesia ranks as the third largest cassava producer country, Indonesia still imports cassava starch to meet the domestic demand in food and non-food industries. Gamma ray irradiation has been implemented to generate cassava mutants in order to support development of superior cassava variety, especially high yield and high starch content, especially high yield and high starch content. The objectives of this research were to evaluate the yield potential and the starch content of gamma irradiated 40 putative cassava mutants at $M_{1} V_{4}$ generation. This research was arranged in randomized complete block design with three replications and conducted at Cikabayan Experimental Field, IPB, Bogor, from May 2016 to March 2017. The starch content was measured using gravimetric methods. The results showed that five mutants, G2142, G3151, G2141, G1143, and G3111, had higher tuber weight per plant (6-7 $\mathrm{kg}$ per plant) compared to the background 'Gajah' genotype (4.7 kg per plant). 'G2112' mutant genotype showed higher starch content (23.86\%) compared to the background 'Gajah' genotype (17.65\%). The specific gravity (SG) was positively correlated with starch content $(r=0.905)$, indicated that the higher the $S G$, the higher the starch content of cassava.
\end{abstract}

Keywords: gravimetric, mutant, specific gravity $(S G)$, yield

\section{ABSTRAK}

Ubi kayu merupakan salah satu tanaman utama penghasil pati. Indonesia adalah negara penghasil ubi kayu terbesar ke-tiga, namun demikian Indonesia masih mengimpor pati ubi kayu sebagai bahan baku industri pangan dan non-pangan. Iradiasi sinar gamma dapat diaplikasikan untuk menciptakan mutan ubi kayu, untuk mendukung pengembangan varietas baru ubi kayu dengan produksi dan kandungan pati tinggi. Tujuan penelitian ini adalah mengevaluasi potensi hasil dan kandungan pati dari 40 mutan putatif hasil iradiasi sinar gamma pada generasi $M_{1} V_{4}$. Penelitian dilakukan menggunakan rancangan kelompok lengkap teracak dengan tiga ulangan di Kebun Percobaan Cikabayan, IPB, Bogor dari bulan Mei 2017 sampai Maret 2017. Kandungan pati diukur menggunakan metode gravimetri. Hasil penelitian menunjukkan terdapat lima mutan, yaitu G2142, G3151, G2141, G1143, dan G3111, memiliki bobot umbi yang lebih tinggi per tanaman (6$7 \mathrm{~kg})$ dibandingkan genotipe asal, Gajah $(4.7 \mathrm{~kg})$. Genotipe mutan $\mathrm{G} 2112$ memiliki kandungan pati tertinggi $(23.86 \%)$ dibandingkan genotipe asal (17.65\%). Nilai spesific gravity (SG) berkorelasi positif dengan kandungan pati ( $r=0.905)$, menunjukkan bahwa semakin tinggi nilai $S G$, maka semakin tinggi kandungan pati ubi kayu.

Kata kunci: gravimetri, mutan, produksi, specific gravity (SG)

\section{PENDAHULUAN}

Ubi kayu merupakan salah satu tanaman utama penghasil pati, selain jagung, sorghum, gandum, beras, sagu, dan kentang, dengan karakteristik masing-masing pati

\footnotetext{
* Penulis untuk korespondensi. e-mail: nurul_khumaida@apps. ipb.ac.id
}

berbeda. Pati tersusun atas amilosa (20-30\%) dan amilopektin (70-80\%), dengan enzim yang berperan dalam pembentukan amilosa adalah granule bound starch synthase (GBSSI) dan enzim yang berperan dalam pembentukan amilopektin adalah soluble starch synthases (SSs), starch branching enzymes (SBE), dan starch debranching enzymes (DBE) (Keeling dan Myers, 2010). Pati digunakan sebagai bahan baku industri pada sektor pangan dan non-pangan (AlcazarAlay dan Meireles, 2015). Pada sektor pangan, pati dapat 
digunakan langsung atau diolah menjadi produk turunan, misalnya sebagai bahan pengental (Waterschoot et al., 2015), sedangkan pada industri non-pangan, pati digunakan pada industri kertas dan kayu lapis, industri kimia dan farmasi, industri pakan ternak, industri tekstil, industri plastik (Alcazar-Alay dan Meireles, 2015).

Data ekspor dan impor pati dari Kemenperin (2017) menunjukkan bahwa kebutuhan pati di Indonesia sangat banyak jika dilihat dari selisih nilai ekspor dan impor. Tahun 2015, nilai ekspor pati ubi kayu sebesar US\$ 5.59 juta dan nilai impor sebesar US\$256.4 juta, namun tahun 2016 nilai ekspor dan impor mengalami penurunan. Nilai ekspor dan impor pati ubi kayu untuk tahun 2016 sebesar US\$ 5.04 juta, namun demikian, nilai impor masih di atas nilai ekspor. Data ini menunjukkan bahwa kebutuhan pati ubi kayu di Indonesia masih cukup tinggi, dengan demikian, diperlukan inovasi varietas ubi kayu yang memiliki potensi untuk menghasilkan pati dalam jumlah tinggi.

Peningkatan kandungan pati pada ubi kayu dilakukan pada kualitas dan kuantitas pati yang dihasilkan per genotipe. Penelitian untuk meningkatkan kualitas pati telah dilakukan oleh Zhao et al. (2011), yaitu dengan menurunkan regulasi ekspresi gen GBSSI, yang berperan dalam sintesis amilosa, sehingga diperoleh ubi kayu dengan kandungan amilosa $<5 \%$, sedangkan Karlstrom et al. (2016) melakukan persilangan antara genotipe sumber pati tinggi dengan genotipe dengan karakter agronomi terbaik. Rolland-Sabate et al. (2011) melaporkan bahwa peningkatan kuantitas kandungan pati dapat dilakukan menggunakan iradiasi sinar gamma. Genotipe ubi kayu yang dimutasi menggunakan sinar gamma mengalami perubahan genetik dalam potensinya menghasilkan pati, dapat lebih rendah atau lebih tinggi dari tetuanya (Ceballos et al., 2008; Rahmiati et al., 2016). Kandungan pati yang tinggi selain dipengaruhi secara genetik, juga dipengaruhi oleh fisiologi tanaman. Li et al. (2016) menyatakan bahwa kandungan pati yang terakumulasi pada akar (fresh root) dipengaruhi oleh tingginya kapasitas transport batang stem flow rate (SFR), tingginya sintesis pati (dipengaruhi oleh aktivitas enzimatis) di batang dan rendahnya degradasi di akar, serta tingginya ekspresi gen terkait transport gula pada batang. Selain itu, kondisi lingkungan juga berpengaruh terhadap kandungan pati suatu genotipe, seperti dilaporkan oleh Moreno dan Gourdji (2015), bahwa curah hujan mempengaruhi kandungan pati, tingginya curah hujan akan meningkatkan kandungan pati.

Tekstur umbi ditentukan oleh rasio bahan kering terhadap air pada umbi. Semakin tinggi komposisi bahan kering dan semakin rendah komposisi air pada umbi, mengindikasikan umbi memiliki nilai specific gravity (SG) semakin tinggi. Nilai SG berkorelasi tinggi dengan kandungan pati dan persentase total padatan (Department of Environment and Primary Industries, 2010). Penghitungan kandungan pati menggunakan nilai SG akan memudahkan dalam memprediksi pati yang dapat dihasilkan, karena biasanya pengujian kandungan pati memerlukan waktu lama dan biaya yang cukup mahal.
Tujuan penelitian ini adalah untuk mengevaluasi potensi hasil genotipe mutan ubi kayu asal genotipe Gajah dan kandungan pati menggunakan metode gravimetri.

\section{BAHAN DAN METODE}

Penelitian dilakukan terhadap 40 genotipe mutan hasil iradiasi sinar gamma generasi $\mathrm{M}_{1} \mathrm{~V}_{4}$ dan satu tanaman asal (Gajah). Genotipe Gajah merupakan genotipe lokal asal Kalimantan Timur, dengan potensi hasil tinggi ( $>40$ ton $\mathrm{ha}^{-1}$ ) dan rasa umbi tidak pahit. Iradiasi dilakukan dengan tujuan meningkatkan daya adaptasinya pada lahan bertanah masam dan meningkatkan potensi genotipe dalam menghasilkan pati. Iradiasi generasi $\mathrm{M}_{1} \mathrm{~V}_{1}$ dilakukan pada tahun 2013 di Laboratorium Pusat Aplikasi Teknologi Isotop dan Iradiasi (PATIR), Badan Tenaga Nuklir Nasional (BATAN) menggunakan radiator Gamma Chamber 4000A, menggunakan lima dosis iradiasi $(0,15,30,45$, dan 60 Gy). Tanaman generasi $\mathrm{M}_{1} \mathrm{~V}_{1}$ yang tumbuh adalah setek perlakuan iradiasi 0 dan $15 \mathrm{~Gy}$, sehingga yang dilanjutkan penanaman generasi $M_{1} V_{2}, M_{1} V_{3}$, dan $M_{1} V_{4}$ adalah mutan-mutan hasil iradiasi 15 Gy dan tanaman asal. Pemberian kodefikasi diurutkan dari nama genotipe yaitu Gajah (G), diikuti nomor ulangan asal tanaman dan dosis iradiasi serta nomor tanaman pada generasi sebelumnya. Misalnya G1121, maka pembacaannya adalah genotipe Gajah dari ulangan satu, dengan dosis iradiasi 15 Gy dan tanaman nomor 2 generasi $\mathrm{M}_{1} \mathrm{~V}_{2}$ dan dilanjutkan menjadi tanaman nomor 1 generasi $\mathrm{M}_{1} \mathrm{~V}_{3}$. Seleksi mutan dilakukan pada generasi $\mathrm{M}_{1} \mathrm{~V}_{4}$ dengan karakter produksi tinggi dan kandungan pati tinggi.

Penelitian dilakukan di lahan Kebun Percobaan Cikabayan, Institut Pertanian Bogor (IPB) pada bulan Mei 2016 sampai dengan Maret 2017 menggunakan sistem budidaya standar untuk ubi kayu. Penanaman dilakukan menggunakan rancangan kelompok lengkap teracak (RKLT). Setiap genotipe dalam satu ulangan terdiri atas lima tanaman, dan ditanam dalam tiga ulangan. Pemanenan dilakukan pada saat tanaman ubi kayu berumur sebelas bulan, kemudian dilakukan penimbangan bobot umbi per tanaman, bobot umbi di udara (x) dan di dalam air (y). Penimbangan bobot umbi per tanaman dilakukan pada seluruh umbi yang dihasilkan per tanaman, sedangkan bobot umbi di udara dilakukan pada umbi yang berukuran besar atau umbi ekonomis (panjang $\geq 20 \mathrm{~cm}$ ). Penghitungan estimasi kandungan pati menggunakan metode gravimetri (Kawano et al., 1987), yaitu dengan mencari nilai SG dengan rumus $\mathrm{SG}=(\mathrm{x} /(\mathrm{x}-\mathrm{y}))$ kemudian dimasukkan dalam rumus kandungan pati $(\%)=(112.1 \mathrm{x}$ SG)-106.4. Penghitungan kandungan pati metode gravimetri menggunakan nilai $\mathrm{SG}$, dimana nilai SG tersebut menentukan total padatan pada umbi (van Niekerk et al., 2016).

Analisis data yang dilakukan adalah analisis sidik ragam, untuk mengetahui pengaruh perlakuan terhadap genotipe yang diamati, analisis korelasi untuk mengetahui keeratan hubungan antara karakter bobot umbi dengan kandungan pati, dan analisis heritabilitas untuk menentukan karakter terkait kandungan pati yang dapat digunakan 
sebagai karakter seleksi. Nilai heritabilitas arti luas $\left(h^{2} b s\right)$ dihitung menggunakan rumus $h^{2} b s=\left(\sigma^{2} g / \sigma^{2} p\right) \times 100 \% ; \sigma^{2} g$ $=(\mathrm{KTm}-\mathrm{KTe}) / \mathrm{r} ; \sigma^{2} \mathrm{p}=\sigma^{2} \mathrm{~g}+\sigma^{2} \mathrm{e} ; \sigma^{2} \mathrm{e}=\mathrm{KTe} / \mathrm{r}$, dimana $\mathrm{h}^{2} \mathrm{bs}$ $=$ heritabilitas arti luas; $\sigma^{2} \mathrm{~g}=$ ragam genetik (mutan); $\sigma^{2} \mathrm{p}=$ ragam fenotip; $\sigma^{2} \mathrm{e}=$ ragam lingkungan; $\mathrm{KTm}=$ Kuadrat tengah mutan; $\mathrm{KTe}=$ Kuadrat tengah galat; $\mathrm{r}=$ ulangan . Nilai heritabilitas (\%) dikelompokkan menjadi tiga, yaitu rendah (nilai $\mathrm{h}^{2}$ bs $0 \%-20 \%$ ),sedang (nilai $\mathrm{h}^{2}$ bs 20\%-50\%), dan tinggi (nilai $\mathrm{h}^{2} \mathrm{bs}>50 \%$ ) (Sobir dan Syukur, 2015). Analisis sidik ragam, uji lanjut Dunnett dan analisis korelasi dilakukan menggunakan program Statistical Tool for Agricultural Research (STAR), sedangkan penghitungan heritabilitas menggunakan Ms. Excel.

\section{HASIL DAN PEMBAHASAN}

Penelitian pemuliaan ubi kayu dilakukan selain untuk meningkatkan produktivitas umbi (fresh root), juga untuk meningkatkan kualitas umbinya, seperti peningkatan kandungan pati. Populasi mutan genotipe Gajah generasi $\mathrm{M}_{1} \mathrm{~V}_{4}$ sudah stabil secara genetik pada karakter bobot umbi (data tidak ditampilkan) dan pada analisis produksi, diperoleh informasi bahwa beberapa genotipe memiliki bobot umbi per tanaman relatif tinggi dibandingkan tetuanya (4.70 kg per tanaman). Empat genotipe memiliki potensi menghasilkan umbi $>6 \mathrm{~kg}$ (Gambar 1), sehingga potensi produksi umbinya adalah \pm 50 ton $\mathrm{ha}^{-1}$ (asumsi populasi tanaman per hektar (ha) 8000 tanaman). Genotipe G2111 memiliki potensi menghasilkan umbi per tanaman mencapai $7.2 \mathrm{~kg}$ (Tabel 2), sehingga potensi umbi yang dihasilkan dari genotipe tersebut mencapai \pm 60 ton $\mathrm{ha}^{-1}$. Pengamatan kimera dilakukan pada karakter kualitatif, namun pada populasi $\mathrm{M}_{1} \mathrm{~V}_{4}$ tidak teramati adanya kimera (data tidak ditampilkan).

Berdasarkan hasil analisis sidik ragam (Tabel 1), genotipe berbeda nyata pada beberapa karakter yang terkait dengan kandungan pati. Penghitungan kandungan pati diawali dengan penghitungan nilai SG, yang menentukan total padatan pada umbi. Nilai SG pada penelitian ini lebih dari satu (Tabel 2), yang menunjukkan bahwa kerapatan jenis umbi lebih rapat dibandingkan kerapatan jenis air (Waluyo et al., 2015), karena kerapatan jenis air adalah $1 \mathrm{~kg}$ $\mathrm{m}^{-3}$. Nilai SG dikelompokkan menjadi tiga kategori, yaitu rendah $(<1.077)$, antara (1.077-1.086), dan tinggi $(>1.086)$ (Fitzpatrick et al., 1969).

Hasil uji lanjut (Tabel 2) menunjukkan bahwa keragaan karakter yang diamati sangat luas. Nilai rata-rata tertinggi untuk bobot umbi adalah $7.2 \mathrm{~kg}$ pada genotipe G3111, dan rata-rata terendah adalah $2.78 \mathrm{~kg}$ pada genotipe G1144. Bobot umbi ini menentukan banyaknya umbi yang digunakan untuk pengukuran kandungan pati, semakin besar bobot umbi yang diperoleh per tanaman maka bobot umbi yang digunakan untuk pengukuran kandungan pati semakin besar. Bobot umbi di udara rata-rata tertinggi adalah $5.25 \mathrm{~kg}$ pada genotipe G1143, sedangkan ratarata terendah adalah $2.05 \mathrm{~kg}$ pada genotipe G1153. Bobot umbi di air rata-rata tertinggi adalah $0.58 \mathrm{~kg}$ pada genotipe G2112, sedangkan rata-rata terendah berturut-turut adalah $0.18 \mathrm{~kg}$ dan $0.19 \mathrm{~kg}$ pada genotipe G1144 dan G3141. Rata-rata karakter kandungan pati tertinggi adalah $23.86 \%$ pada genotipe G2112, sedangkan terendah adalah $12.60 \%$ pada genotipe G3154. Penelitian mengenai kandungan pati sudah pernah dilakukan sebelumnya, dan menghasilkan estimasi kandungan pati yang beragam bergantung pada genotipe, metode, umur panen umbi, lokasi penanaman dan musim tanam (Baafi dan Safo-Kantanka, 2007; Sanchez et al., 2009; Rolland-Sabate et al., 2011; Nurdjanah et al., 2007; Mtunguja et al., 2015; Mohammed, 2016; Subekti et al., 2017). Anggraini et al. (2009) dan Rahmiati et al. (2016) menyampaikan bahwa genotipe yang berbeda akan mempengaruhi karakteristik sifat fisikokimia umbi yang dihasilkan, termasuk kandungan pati dan karakteristik pati yang dihasilkan (ukuran butir pati, suhu pengentalan, kandungan fosfat). Penelitian Shin et al. (2011) pada ubi

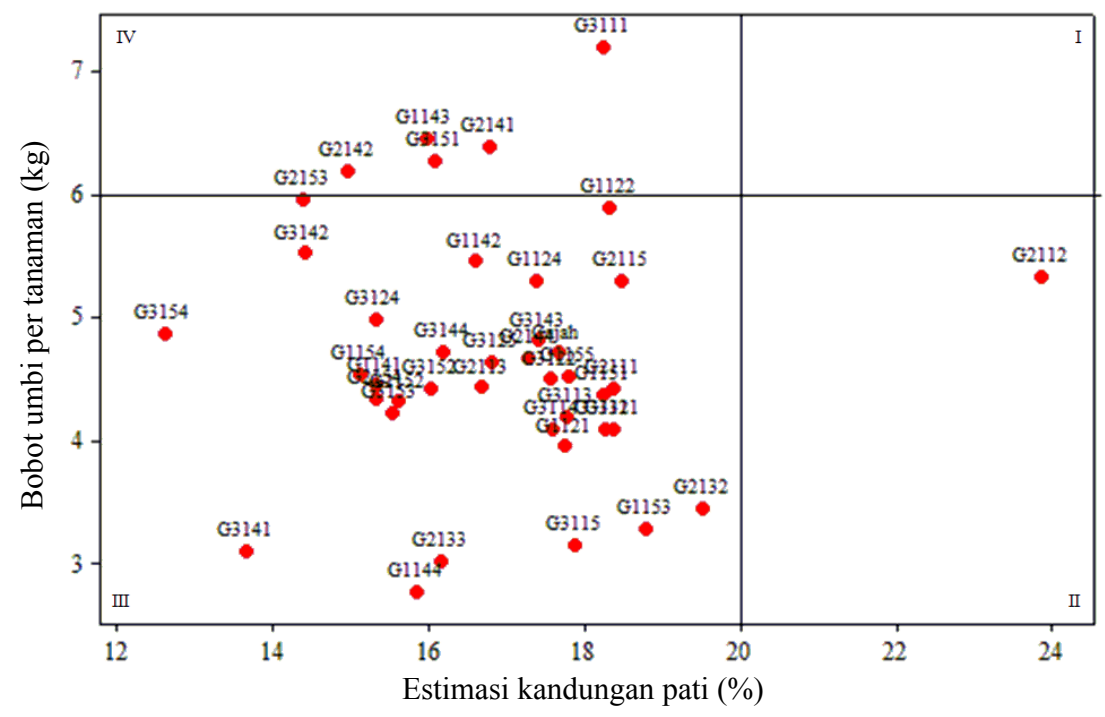

Gambar 1. Pengelompokan genotipe ubi kayu asal Gajah berdasarkan bobot umbi segar per tanaman dan estimasi kandungan pati 
Tabel 1. Rekapitulasi hasil analisis ragam karakter kuantitatif umbi beberapa genotipe ubi kayu generasi $\mathrm{M}_{1} \mathrm{~V}_{4}$ asal Gajah

\begin{tabular}{lccc}
\hline & KT genotipe & KT blok & KT galat \\
\hline Bobot umbi per tanaman $(\mathrm{kg})$ & $2.996^{*}$ & 12.354 & 1.238 \\
Bobot umbi di udara $(\mathrm{kg})$ & $1.499^{*}$ & 3.449 & 0.764 \\
Bobot umbi di air $(\mathrm{kg})$ & $0.022^{*}$ & 0.215 & 0.012 \\
Estimasi kandungan pati (\%) & $10.810^{*}$ & 110.490 & 6.430 \\
\hline
\end{tabular}

Keterangan: * = berbeda nyata pada taraf 1 dan $5 \%$; tn = tidak berbeda nyata

jalar dengan perlakuan iradiasi sinar gamma menunjukkan tanaman mutan mampu menghasilkan kandungan pati yang lebih tinggi dibandingkan genotipe asal atau tetuanya. Saithong et al. (2013) melaporkan bahwa tanaman mutan hasil iradiasi sinar gamma mengalami perubahan dalam potensinya menghasilkan pati, karena diduga sinar gamma mempengaruhi susunan nukleotida dari gen tanaman, sehingga mempengaruhi siklus biosintesis pati, yaitu siklus calvin, sintesis sukrosa, dan penyimpanan pati, dan perubahan yang terjadi dapat ke arah positif (kandungan pati meningkat) maupun negatif (kandungan pati menurun).

Berdasarkan nilai estimasi kandungan pati, diperoleh informasi bahwa genotipe mutan G2112 mampu menghasilkan kandungan pati yang lebih tinggi dibandingkan genotipe tetua dan paling tinggi dibanding mutan yang lain. Genotipe G2112 diduga mengalami mutasi maju (forward mutation), yaitu mutasi yang menghasilkan mutan baru dengan karakter yang semakin menjauhi karakter tanaman asalnya (Aisyah et al., 2009).

Pengelompokan genotipe menggunakan scatterplot dilakukan untuk memperoleh informasi genotipe-genotipe yang memiliki bobot umbi dan kandungan pati tinggi. Hasil scatterplot menunjukkan bahwa tidak terdapat genotipe yang mengisi kuadran satu, sedangkan kuadran dua hanya berisi satu genotipe yaitu G2112 (Gambar 1). Genotipe G2112 memiliki kandungan pati tertinggi yaitu $23.86 \%$, namun memiliki bobot umbi per tanaman $5.3 \mathrm{~kg}$, sehingga potensi umbinya adalah \pm 42.40 ton $\mathrm{ha}^{-1}$ dengan estimasi pati yang dapat dihasilkan sebesar 10.12 ton $\mathrm{ha}^{-1}$. Kuadran empat berisi informasi genotipe dengan bobot umbi $>6 \mathrm{~kg}$, yaitu pada genotipe G2142, G3151, G2141, G1143, dan G3111, namun hanya satu genotipe yang memiliki estimasi kandungan pati cukup tinggi yaitu G3111. Potensi genotipe G3111 untuk menghasilkan umbi adalah \pm 57.60 ton ha $^{-1}$ dengan estimasi pati yang dihasilkan sebesar 10.50 ton $\mathrm{ha}^{-1}$. Maharani et al. (2015) melakukan iradiasi sinar gamma pada beberapa genotipe ubi kayu, dan diperoleh mutan dengan bobot umbi per tanaman lebih dari $10 \mathrm{~kg}$. Perbedaan potensi dalam menghasilkan umbi diduga karena pengaruh iradiasi yang bersifat acak, sehingga perubahan fisiologi antar tanaman berbeda.

Analisis hubungan atau korelasi dilakukan untuk mengetahui karakter yang mempengaruhi kandungan pati suatu genotipe. Karakter yang berkorelasi positif dengan estimasi kandungan pati adalah bobot umbi di air dengan nilai korelasi 0.697 dan SG dengan nilai korelasi 0.949 . Nilai korelasi yang semakin tinggi atau mendekati satu menunjukkan semakin eratnya hubungan antar karakter, hal ini menunjukkan SG berpengaruh lebih besar terhadap kandungan pati dibanding bobot umbi di air. Semakin besar nilai SG maka kandungan pati semakin tinggi, korelasi yang sama juga diperoleh pada ubi jalar (Waluyo et al., 2015) dan kentang (Mohammed, 2016). Namun demikian, dari informasi bobot umbi di dalam air ketika penimbangan umbi di lapang, dapat diduga genotipe yang memiliki kandungan pati tinggi, sehingga dapat secara cepat dipilih genotipe dengan kandungan pati tinggi. Regresi linier antara nilai SG dengan estimasi kandungan pati menghasilkan nilai korelasi (r) sebesar 0.905. Nilai tersebut mendekati satu, yang menunjukkan bahwa nilai SG berpengaruh besar terhadap estimasi kandungan pati, yaitu sebesar $90.5 \%$, sedangkan sisanya adalah pengaruh dari variabel yang lain.

Heritabilitas merupakan hubungan antara ragam genotipe dengan lingkungan, yang menggambarkan seberapa jauh fenotipe yang tampak sebagai refleksi dari genotipe (Sobir dan Syukur, 2015). Nilai heritabilitas dihitung untuk mengetahui potensi karakter diturunkan pada generasi selanjutnya. Empat karakter yang diujikan (Tabel 3) menunjukkan bahwa karakter bobot umbi dan bobot umbi di udara mempunyai heritabilitas arti luas $\left(\mathrm{h}^{2} \mathrm{bs}\right)$ tinggi, sedangkan karakter bobot umbi di air dan estimasi kandungan pati memiliki $\mathrm{h}^{2} \mathrm{bs}$ yang sedang. Visscher et al. (2008) menyatakan, bahwa karakter yang memiliki nilai $\mathrm{h}^{2}$ bs tinggi berarti faktor genetik berpengaruh lebih besar dibandingkan dengan faktor lingkungan dan sifat-sifat genetik dari genotipe tersebut dapat diturunkan pada generasi selanjutnya, sehingga dapat dilakukan seleksi berdasarkan peubah tersebut. Dengan demikian, karakter kandungan pati yang dicari menggunakan metode pendugaan pati gravimetri, tidak dapat digunakan untuk kriteria seleksi pada genotipe dengan potensi kandungan pati tinggi, karena memiliki nilai $\mathrm{h}^{2}$ bs yang sedang, dimana pengaruh lingkungan lebih besar dibandingkan pengaruh genetik. Jika nilai kandungan pati akan digunakan sebagai karakter seleksi, maka pengukuran kandungan pati harus dilakukan menggunakan analisis pati di laboratorium, sehingga nilai kandungan pati yang diperoleh bukan merupakan pendugaan. 
Tabel 2. Keragaan karakter kuantitatif umbi beberapa genotipe ubi kayu generasi $\mathrm{M}_{1} \mathrm{~V}_{4}$ asal Gajah

\begin{tabular}{|c|c|c|c|c|c|}
\hline \multirow[b]{2}{*}{ Genotipe } & \multirow{2}{*}{$\begin{array}{c}\text { Bobot umbi } \\
\text { per tanaman } \\
(\mathrm{kg})\end{array}$} & \multicolumn{2}{|c|}{ Komponen penghitungan gravimetri } & \multirow{2}{*}{$\begin{array}{l}\text { Nilai specific } \\
\text { gravity } \\
\text { (SG) }\end{array}$} & \multirow{2}{*}{$\begin{array}{c}\text { Estimasi } \\
\text { kandungan pati } \\
(\%)\end{array}$} \\
\hline & & $\begin{array}{l}\text { Bobot umbi } \\
\text { di udara }(\mathrm{kg})\end{array}$ & $\begin{array}{c}\text { Bobot umbi } \\
\text { di air }(\mathrm{kg})\end{array}$ & & \\
\hline Gajah & $4.72 b-h$ & $3.80 \mathrm{a}-\mathrm{h}$ & $0.37 \mathrm{a}-\mathrm{f}$ & 1.105 & $17.65 b-d$ \\
\hline G1121 & $3.96 \mathrm{~d}-\mathrm{h}$ & $3.31 \mathrm{c}-\mathrm{h}$ & $0.33 b-f$ & 1.107 & $17.74 b-d$ \\
\hline G1122 & $5.89 \mathrm{a}-\mathrm{d}$ & $4.54 \mathrm{a}-\mathrm{d}$ & $0.47 \mathrm{a}-\mathrm{c}$ & 1.111 & $18.31 \mathrm{bc}$ \\
\hline G1124 & $5.30 \mathrm{a}-\mathrm{g}$ & $4.28 \mathrm{a}-\mathrm{e}$ & $0.41 \mathrm{a}-\mathrm{e}$ & 1.106 & $17.37 \mathrm{~b}-\mathrm{d}$ \\
\hline G1141 & $4.45 b-h$ & $3.53 \mathrm{a}-\mathrm{h}$ & $0.29 \mathrm{c}-\mathrm{f}$ & 1.089 & $15.32 b-d$ \\
\hline G1142 & $5.46 \mathrm{a}-\mathrm{e}$ & $4.46 \mathrm{a}-\mathrm{d}$ & $0.39 a-f$ & 1.095 & $16.60 \mathrm{~b}-\mathrm{d}$ \\
\hline G1143 & $6.46 \mathrm{ab}$ & $5.25 \mathrm{a}$ & $0.46 \mathrm{a}-\mathrm{c}$ & 1.092 & $15.96 b-d$ \\
\hline G1144 & $2.78 \mathrm{~h}$ & $2.36 \mathrm{gh}$ & $0.18 \mathrm{f}$ & 1.093 & $15.85 b-d$ \\
\hline G1151 & $4.38 b-h$ & $3.64 a-h$ & $0.37 \mathrm{a}-\mathrm{f}$ & 1.112 & $18.24 b c$ \\
\hline G1153 & $3.28 \mathrm{e}-\mathrm{h}$ & $2.05 \mathrm{~h}$ & $0.20 \mathrm{ef}$ & 1.115 & $18.77 b c$ \\
\hline G1154 & $4.55 b-h$ & $3.91 \mathrm{a}-\mathrm{g}$ & $0.30 c-f$ & 1.083 & $15.12 b-d$ \\
\hline G1155 & $4.53 b-h$ & $3.54 \mathrm{a}-\mathrm{h}$ & $0.35 b-f$ & 1.106 & $17.78 b-d$ \\
\hline G2111 & $4.43 b-h$ & $3.44 b-h$ & $0.35 b-f$ & 1.112 & $18.37 \mathrm{bc}$ \\
\hline G2112 & 5.33a-f & $3.98 \mathrm{a}-\mathrm{g}$ & $0.58 \mathrm{a}$ & 1.166 & $23.86 \mathrm{a}$ \\
\hline G2113 & $4.44 b-h$ & $3.85 \mathrm{a}-\mathrm{g}$ & $0.36 b-f$ & 1.099 & $16.68 b-d$ \\
\hline G2115 & $5.30 \mathrm{a}-\mathrm{g}$ & $4.15 a-f$ & $0.43 a-d$ & 1.115 & $18.46 b c$ \\
\hline G2132 & $3.46 \mathrm{e}-\mathrm{h}$ & $2.79 \mathrm{~d}-\mathrm{h}$ & $0.30 \mathrm{c}-\mathrm{f}$ & 1.132 & $19.51 b$ \\
\hline G2133 & $3.03 \mathrm{gh}$ & $2.37 \mathrm{f}-\mathrm{h}$ & $0.21 \mathrm{~d}-\mathrm{f}$ & 1.120 & $16.15 b-d$ \\
\hline G2141 & $6.39 \mathrm{ab}$ & $4.91 \mathrm{a}-\mathrm{c}$ & $0.44 \mathrm{a}-\mathrm{c}$ & 1.098 & $16.77 \mathrm{~b}-\mathrm{d}$ \\
\hline G2142 & $6.20 \mathrm{a}-\mathrm{d}$ & $4.53 a-d$ & $0.34 b-f$ & 1.084 & $14.96 b-d$ \\
\hline G2144 & $4.68 \mathrm{~b}-\mathrm{h}$ & $4.18 \mathrm{a}-\mathrm{e}$ & $0.39 \mathrm{a}-\mathrm{f}$ & 1.102 & $17.28 \mathrm{~b}-\mathrm{d}$ \\
\hline G2152 & $4.32 \mathrm{~b}-\mathrm{h}$ & $3.36 \mathrm{~b}-\mathrm{h}$ & $0.28 \mathrm{c}-\mathrm{f}$ & 1.086 & $15.61 b-d$ \\
\hline G2153 & $5.96 a-d$ & $4.20 \mathrm{a}-\mathrm{e}$ & $0.29 \mathrm{c}-\mathrm{f}$ & 1.070 & $14.39 \mathrm{~b}-\mathrm{d}$ \\
\hline G2154 & $4.35 \mathrm{~b}-\mathrm{h}$ & $3.10 \mathrm{~d}-\mathrm{h}$ & $0.25 \mathrm{c}-\mathrm{f}$ & 1.083 & $15.32 b-d$ \\
\hline G3111 & $7.20 \mathrm{a}$ & $5.12 \mathrm{ab}$ & $0.53 \mathrm{ab}$ & 1.112 & $18.24 b c$ \\
\hline G3113 & $4.20 \mathrm{~b}-\mathrm{h}$ & $3.31 \mathrm{c}-\mathrm{h}$ & $0.32 b-f$ & 1.105 & $17.76 \mathrm{~b}-\mathrm{d}$ \\
\hline G3114 & $4.10 \mathrm{c}-\mathrm{h}$ & $3.78 \mathrm{a}-\mathrm{h}$ & $0.36 \mathrm{~b}-\mathrm{f}$ & 1.107 & $17.58 b-d$ \\
\hline G3115 & $3.16 \mathrm{f}-\mathrm{h}$ & $3.05 \mathrm{~d}-\mathrm{h}$ & $0.30 \mathrm{c}-\mathrm{f}$ & 1.107 & $17.88 b c$ \\
\hline G3121 & $4.10 \mathrm{c}-\mathrm{h}$ & $3.48 \mathrm{a}-\mathrm{h}$ & $0.36 b-f$ & 1.118 & $18.37 \mathrm{bc}$ \\
\hline G3122 & 4.50b-h & $3.58 \mathrm{a}-\mathrm{h}$ & $0.35 b-f$ & 1.107 & $17.55 b-d$ \\
\hline G3124 & 4.98b-h & $3.62 \mathrm{a}-\mathrm{h}$ & $0.29 c-f$ & 1.087 & $15.31 \mathrm{~b}-\mathrm{d}$ \\
\hline G3125 & 4.64b-h & $3.50 \mathrm{a}-\mathrm{h}$ & $0.33 b-f$ & 1.097 & $16.79 b-d$ \\
\hline G3131 & $4.09 \mathrm{c}-\mathrm{h}$ & $3.19 \mathrm{c}-\mathrm{h}$ & $0.32 b-f$ & 1.121 & $18.25 b c$ \\
\hline G3141 & $3.10 \mathrm{f}-\mathrm{h}$ & $2.50 \mathrm{e}-\mathrm{h}$ & $0.19 \mathrm{f}$ & 1.085 & $13.66 \mathrm{~cd}$ \\
\hline G3142 & 5.53a-e & 3.76a-h & $0.27 \mathrm{c}-\mathrm{f}$ & 1.076 & $14.39 \mathrm{~b}-\mathrm{d}$ \\
\hline G3143 & $4.82 b-h$ & 3.66a-h & $0.35 b-f$ & 1.104 & $17.41 \mathrm{~b}-\mathrm{d}$ \\
\hline G3144 & $4.73 b-h$ & $4.00 \mathrm{a}-\mathrm{g}$ & $0.35 b-f$ & 1.091 & $16.19 b-d$ \\
\hline G3151 & $6.27 \mathrm{a}-\mathrm{c}$ & $4.15 a-f$ & $0.36 b-f$ & 1.094 & $16.07 \mathrm{~b}-\mathrm{d}$ \\
\hline G3152 & $4.43 \mathrm{~b}-\mathrm{h}$ & $4.31 \mathrm{a}-\mathrm{d}$ & $0.35 b-f$ & 1.090 & $16.03 \mathrm{~b}-\mathrm{d}$ \\
\hline G3153 & $4.24 b-h$ & $3.87 \mathrm{a}-\mathrm{g}$ & $0.32 b-f$ & 1.090 & $15.52 b-d$ \\
\hline G3154 & $4.88 \mathrm{~b}-\mathrm{h}$ & $3.48 \mathrm{a}-\mathrm{h}$ & $0.21 \mathrm{~d}-\mathrm{f}$ & 1.062 & $12.60 \mathrm{~d}$ \\
\hline
\end{tabular}

Keterangan: Angka pada setiap kolom karakter yang diikuti huruf yang sama menunjukkan tidak berbeda nyata berdasarkan uji selang berganda Duncan pada taraf uji $5 \%$ 
Tabel 3. Nilai duga heritabilitas arti luas (h²bs) karakter kuantitatif umbi ubi kayu generasi $\mathrm{M}_{1} \mathrm{~V}_{4}$

\begin{tabular}{lccccc}
\hline Karakter & $\sigma^{2} \mathrm{e}$ & $\sigma^{2} \mathrm{~g}$ & $\sigma^{2} \mathrm{p}$ & $\mathrm{h}^{2} \mathrm{bs}$ & $\mathrm{Kriteria}$ \\
\hline Bobot umbi per tanaman $(\mathrm{kg})$ & 0.413 & 0.611 & 1.024 & 59.689 & Tinggi \\
Bobot umbi di udara (kg) & 0.255 & 0.258 & 0.512 & 50.284 & Tinggi \\
Bobot umbi di air (kg) & 0.004 & 0.004 & 0.007 & 47.149 & Sedang \\
Estimasi kandungan pati (gravimetri) & 2.143 & 1.536 & 3.680 & 41.751 & Sedang \\
\hline
\end{tabular}

Keterangan: $\sigma^{2} \mathrm{e}=$ ragam lingkungan; $\sigma^{2} \mathrm{~g}=$ ragam genetik; $\sigma^{2} \mathrm{p}=$ ragam fenotipe; $\mathrm{h}^{2} \mathrm{bs}=$ heritabilitas arti luas $(\%)$

\section{KESIMPULAN}

Genotipe mutan memiliki potensi yang berbeda dalam menghasilkan pati. Kandungan pati tertinggi sebesar $23.86 \%$ pada genotipe G2112, dan terkecil sebesar $12.60 \%$ pada genotipe G3154. Karakter yang berpengaruh langsung terhadap kandungan pati suatu genotipe adalah bobot umbi di air dan nilai specific gravity. Kandungan pati yang diukur menggunakan metode grafimetri memiliki $\mathrm{h}^{2} \mathrm{bs}$ kriteria sedang, menunjukkan pengaruh lingkungan lebih besar dibanding pengaruh genetik, sehingga tidak dapat digunakan sebagai karakter seleksi.

\section{UCAPAN TERIMA KASIH}

Ucapan terima kasih disampaikan kepada Kementerian Riset, Teknologi, dan Pendidikan Tinggi untuk Dana Riset Skema KLN PI dan Penelitian Berbasis Kompetensi atas nama Dr. Nurul Khumaida dan Tim.

\section{DAFTAR PUSTAKA}

Aisyah, S.I., H. Aswidinnoor, A. Saefuddin, B. Marwoto, S. Sastrosumarjo. 2009. Induksi mutasi pada stek pucuk anyelir (Dianthus caryophyllus Linn.) melalui iradiasi sinar gamma. J. Agron. Indonesia 37:62-70.

Alcazar-Alay, S.C., M.A.A. Meireles.2015.Physicochemical properties, modifications and applications of starches from different botanical sources. Food Sci. Technol. 35:215-236.

Angraini, V., E. Sudarmonowati, N.S. Hartati, L. Suurs, R.G.F Visser. 2009. Characterization of cassava starch attributes of different genotypes. Starch/Starke 61:472-481.

Baafi, E., O. Safo-Kantanka. 2007. Effect of genotype, age, and location on cassava starch yield and quality. J. Agron. 6:581-585.

Ceballos, H., T. Sanchez, K. Denyer, A.P. Tofindo, E.A. Rosero, D. Dufour, A. Smith, N. Morante, J.C. Perez, B. Fahy. 2008. Induction and identification of a small-granule, high-amylose mutant in cassava (Manihot esculenta Crantz). J. Agric. Food Chem. 56:7215-7222.
Department of Environment and Primary Industries. 2010. Potatoes: Measurement of specific gravity. http:// agriculture.vic.gov.au [1 Agustus 2017].

Fitzpatrick, J.J., W.L. Porter, V.C. Houghland. 1969. Continued studies of the relationship of specific gravity to total solids of potato. American Potato J. 46:120-127.

Karlstrom A, F. Calle, S. Salazar, N. Morante, D. Dufour, H. Ceballos. 2016. Biological implications in cassava for the production of amylose-free starch: impact on root yield and related traits. Front. Plant Sci. 7:604.

Kawano, K., W.M.G. Fukuda, U. Cenpukdee. 1987. Genetic and environmental effect on dry matter content of cassava root. Crop Sci. 27:69-74.

Keeling, P.L., A.M. Myers. 2010. Biochemistry and genetics of starch synthesis. Annu. Rev. Food Sci. Technol. 1:271-303.

Kementerian Perindustrian. 2017. Ekspor- Impor Pati. http://www.kemenperin.go.id [17 Juli 2017].

Li, Y.Z., J.Y. Zhao, S.M. Wu, X.W. Fan, X.L. Luo, B.S. Chen. 2016. Characters related to higher starch accumulation in cassava storage roots. Sci. Report 6:1-17.

Maharani, S., N. Khumaida, M. Syukur, S.W. Ardie. 2015. Radiosensitivitas dan keragaman ubi kayu (Manihot esculenta Crantz.) hasil iradiasi sinar gamma. J. Agron. Indonesia 43:111-117.

Mohammed, W. 2016. Specific gravity, dry matter content, and starch content of potato (Solanum tuberosum L.) varieties cultivated in Eastern Ethiopia. East African J. Sci. 10:87-102.

Moreno, P., S. Gourdji. 2015. Cassava Starch Content and Its Relationship With Rainfall. CCAFS Info Note. Copenhagen, Denmark: CGIAR Research Program on Climate Change, Agriculture and Food Security (CCAFS). 
Mtunguja, M.K., H.S. Laswai, E. Kanju, J. Ndunguru, Y.C. Muzanilla. 2015. Effect of genotype and genotype by environment interaction on total cyanide content, fresh root, and starch yield in farmer- preferred cassava landraces in Tanzania. Food Sci. Nutr. 4:791801.

Nurdjanah, S., Susilawati, M.R. Sabatini. 2007. Prediksi kadar pati ubi kayu (Manihot esculenta) pada berbagai umur panen menggunakan penetrometer. J. Tekno. Industri Hasil Pertanian 12:65-73.

Rahmiati, T.M., Y.A. Purwanto, S. Budijanto, N. Khumaida. 2016. Sifat fisikokimia tepung dari 10 genotipe ubi kayu (Manihot esculenta Crantz) hasil pemuliaan. Agritech 36:459-466.

Rolland-Sabate, A., T. Sanchez, A. Buleon, P. Colonna, B. Jaillais, H. Ceballos, D. Dufour. 2011.Structural characterization of novel cassava starches with low and high-amylose contents in comparison with other commercial sources. Food Hydrocolloids 27:161174.

Saithong, T., O. Rongsirikul, S. Kalapanulak, P. Chiewchankaset, W. Siriwat, S. Netrphan, M. Suksangpanomrung, A. Meechai, S. Cheevadhanarak. 2013. Starch biosynthesis in cassava: a genomebased pathway reconstruction and its exploitation in data integration. BMS Sys. Biol. 2:75-87.

Sanchez, T., E. Salcedo, H. Ceballos, D. Dufour, G. Mafia, N. Morante, F. Calle, J.C. Perez, D. Debouck, G. Jaramillo, I.X. Moreno. 2009. Screening of starch quality traits in cassava (Manihot esculenta Crantz). Intl. J. of the Investigation, Processing and Use of Carbohydrates and Their Derivates 61:12-19.

Shin, J.M., B.K. Kim, S.G. Seo, S.B. Jeon, J.S. Kim, B.K. Jun, S.Y. Kang, J.S. Lee, M.N. Chung, S.H. Kim.
2011. Mutation breeding of sweet potato by gammaray radiation. Afr. J. Agric. Res. 6:1447-1454.

Sobir, M. Syukur. 2015. Genetika Tanaman. IPB Press, Bogor (INA).

Subekti, I., N. Khumaida, S.W. Ardie. 2017. Identification of potentially high yielding irradiated cassava 'Gajah' genotype with different geographic coordinates. IOP Conf. Series: Earth Env. Sci. 54:1-7.

Van Niekerk, C., H.C. Schonfeldt, N. Hall, B. Pretorius. 2016. The reliability of dry matter, specific gravity, starch and glycaemic index to classify potatoes. Intl. J. Agric. Env. Res. 2:1420-1437.

Visscher, P.M., W.G. Hill, N.R. Wray. 2008. Heritability in the genomics era concepts and misconceptions. Nature Rev. 9:255-266.

Waluyo, B., C.U. Zanetta, A.A. Roosda, G.D. Hazbi, A. Kurniawan. 2015. Penentuan kandungan pati dan bahan kering non destruktif pada ubi jalar dengan pendekatan metode specific gravity. Hal. 293-299. Dalam N. Carsono, O. Mulyani (Eds.). Prosiding Tantangan, Peluang dan Arah Pengembangan. Bandung 3-4 September 2015.

Waterschoot, J., S.V. Gomand, E. Fierens, J.A. Delcour. 2015. Production, structure, physicochemical and functional properties of maize, cassava, wheat, potato and rice starches. Starch-Starke 67:14-29.

Zhao, S., D. Dufour, T. Sanchez, H. Ceballos, P. Zhang. 2011. Development of waxy cassava with different biological and physico-chemical characteristics of starches for industrial applications. Biotech. Bioengineering 108:1925-1935. 